\title{
Palkkatyövoiman käyttö työnjohdon apuna puutarha- ja maatilayrityksissä
}

\author{
Jarkko Leppälä ${ }^{1)}$, Antero Olakivi ${ }^{2)}$ ja Kari Mikko Vesala ${ }^{2)}$ \\ "MTT Taloustutkimus, Latokartanonkaari 9,00790 Helsinki jarkko.leppala@mtt.fi \\ ${ }^{2)}$ Helsingin yliopisto, Sosiaalitieteiden laitos, 00014 Helsingin yliopisto etunimi.sukunimi@helsinki..fi
}

\section{Tiivistelmä}

Palkkatyövoiman johtaminen on yksi nousevista haasteista kasvavien puutarha- ja maatilayritysten toiminnassa. Kasvavilla tiloilla käytetään yhä enemmän erityisesti osa-aikaista työvoimaa ja kausityövoimaa kesän sesonkiluonteisiin töihin. Tällöin työnjohdon haasteet oletettavasti kasvavat. Työn johtamiseen liittyy monia osatehtäviä, jotka yrittäjän on hallittava: työvoiman hankkiminen, työn organisointi, työntekijöiden työtyytyväisyys ja motivointi, hallinto ja palkanlaskenta sekä itse työnjohto ja siihen liittyvät vuorovaikutustilanteet. Ei kuitenkaan ole tiedossa, ovatko palkkatyövoiman ohjaamisen ja työnjohdon käytännöt uudistuneet tilanjohtamisen muuttuvissa tilanteissa, kuten tilan ulkopuolisen tai ulkomaalaisen työvoiman määrän kasvaessa. Yrittäjälle itselleen palkkatyövoima on tarpeellinen resurssi tuotannon ja yritystoiminnan volyymin kasvattamisessa. Olennaista yrittäjän kannalta on myös estää yrittäjän oman työmäärän liikakasvu. Tässä artikkelissa käsiteltiin palkkatyövoiman käyttöä työnjohdon apuna eli työnjohdollisten tehtävien delegoimista palkkatyöntekijöille. Tutkimuskysymyksenä oli, käyttävätkö puutarha- ja maatilayrittäjät palkkatyövoimaa työnjohtotehtävissä, ja minkälaisena johtamiskeinona se tässä yhteydessä näyttäytyy.

Työnjohtotehtäviä on mielekästä delegoida työntekijöille, kun yrityskokoa kasvatetaan. Tyypillisiä tällaisia yrityksiä ovat puutarhayritykset, joilla on paljon kausityövoimaa. Tutkimuksessa haastateltiin tutkimustapauksena itäsuomalaista puutarha- ja maatalousyritystä, jossa kausityövoiman määrä ylitti sata työntekijää. Tilalla oli myös ulkomaalaista työvoimaa. Tutkimustapauksen käytäntöjä verrattiin MTT:n lähettämän kyselyn $(\mathrm{N}=228)$ tuloksiin. Kyselyn vastaajat olivat Maaseudun Työnantajaliittoon kuuluvia puutarha- ja maatilatyönantajia. Kyselyn perusteella työnjohtotehtävien delegoimista työntekijöille ennustivat työnantajavastaajan naissukupuoli ja nuori ikä, tilan suuri kausittaisen työvoiman määrä sekä puutarhaviljely tuotantosuuntana. Työnjohdon delegointia tekeville työnantajille delegointi ilmeni myös haasteellisena. Puutarha- ja maatilan työt ovat turvallisuusmielessä hyvin riskialtis ala. Kyselyn perusteella näyttää siltä, että suurten työvoimamäärien ja osaamisen hallinnan avuksi puutarha- ja maatilayrityksissä tarvitaan uusia johtamisen käytäntöjä, niihin paneutuvaa tutkimusta, koulutusta ja tiedotusta.

Avainsanat: puntarha-ja maatalousyrityksen työvoiman johtaminen, delegointi 


\section{Johdanto}

Artikkelissa käsitellään puutarha- ja maatilojen työnjohtamista ja erityisesti laajenevien tilojen työnjohdollisten tehtävien delegoimisen yleisyyttä, tärkeyttä ja haasteellisuutta. Palkkatyövoiman johtaminen on noussut esiin yhtenä kasvavien puutarha- ja maatilayritysten toiminnallisena haasteena (Rekola, 2003). Usein tiloilla on pyritty käyttämään työntekijöinä oman perheen jäseniä, mutta tuotantovolyymien kasvaessa ne tarvitsevat yhä enemmän osa-aikaista työvoimaa ja kausityövoimaa kesän sesonkiluonteisiin töihin. Suomen puutarhatiloilla oli vuonna 201029000 kausityöntekijää, joista 15000 ulkomaalaisia. (Ovaska ym. 2011). Maatiloilla vakituisten työntekijöiden määrä on vähentynyt, mutta teknisten sovellusten yleistyessä työn johtamisen haasteet liittyvät yhä enemmän työvoiman osaamisen johtamiseen. Tämän lisäksi yleistyvä urakointityön ohjaus maatiloilla näyttää edellyttävän tilan johtajalta uudenlaisia työnjohtotaitoja (Aaltonen 2011; Leppälä ym. 2008; Karttunen ym. 2008). Työnjohtamisen säätelyn kehittyminen on tapahduttava samassa suhteessa työtehtävissä, työn tavoitteissa, työympäristössä ja työn organisoinnissa tapahtuviin muutoksiin (Vartiainen ym. 1989). Maaseudun muuttuvissa työympäristöissä tarvittaisiin joustavuuden ja kontrolloinnin yhdistävää aikaisempaa oivaltavampaa johtamista. Uudet osaamisen haasteet johtamisessa tulee huomioida myös työntekijöiden osaamisen kehittämisessä puutarha-ja maatilayrityksissä (Vesala ja Pyysiäinen 2008; Leppälä ym. 2008).

Työnjohtamiseen liittyy monia vaatimuksia ja tehtäviä, jotka yrittäjän tulisi hallita. On hoidettava soveliaan työvoiman hankkiminen, työn organisointi, työtyytyväisyys, palkka-asiat ja muut paperityöt, työnjohtaminen ja työturvallisuus sekä hankalat vuorovaikutustilanteet kuten riitatilanteet tyylikkäästi (Mattila ym. 2010). Ongelmana kuitenkin on, että palkkatyövoiman työnjohtoa ei ole mahdollisesti puutarhaja maatilayrityksissä tutkittu ja kehitetty tarpeiden mukaisesti. Puutarha - ja maatilojen työnjohtamisessa tulee tulevaisuudessa huomioida alalla tapahtuvia muutoksia. (Mattila ym. 2010; Vesala ja Pyysiäinen 2008).

Työnjohtotehtävien delegointi työntekijöille on yrittäjille uusi työnjohdollinen haaste, kun yrityskoko kasvaa ja toiminnot teknistyvät. Delegointi tarjoaa mahdollisuuksia lisätä ja hallita työvoimaa ja estää yrittäjän oman työmäärän liikakasvua (Karttunen ym. 2008; Leppälä ym. 2008). Delegointi nähdään usein yksinkertaisena tehtävien siirtona työntekijöille, mutta työnjohtotehtävien delegointi vaatii periaatteessa syvällisempää organisaation ja työn tavoitteiden, työntekijöiden psykologisen profiilin ja viestinnän hallintaa (Vartiainen ym. 1989). Tässä artikkelissa tarkastellaan palkkatyövoiman käyttöä puutarhatilatutkimustapauksen ja puutarha- ja maatilayritysten työnantajille suunnatun kyselyaineiston avulla. Kehittyvä puutarhatila on tutkimuskohteena kiinnostava, sillä se antaa mahdollisuuden tarkastella työnjohdollisten haasteiden käytäntöjä suuremmassa tilakontekstissa. Tapaustutkimuksen avulla demonstroimme työnjohtotehtävien delegoinnin mahdollisuutta tiloilla. Kyselytutkimuksella arvioimme sen yleisyyttä ja asemaa työnjohdossa. Tutkimus liittyy maa- ja metsätalousministeriön rahoittamaan Maavoimahankkeeseen, jossa edistetään puutarha- ja maatilayritysten johtamistoimen apuvälineiden kehittämistä.

\section{Aineisto ja menetelmät}

Tutkimuksessa on käytetty useampaa tutkimusotetta, joiden tuloksia on vertailtu ja yhdistelty. Tutkimuksen aineisto koostui erityyppisten tutkimustapaustilojen haastatteluista $(\mathrm{N}=6)$ ja työnantajille tehdystä kyselytutkimuksesta $(\mathrm{N}=228)$. Tässä artikkelissa esitellään itäsuomalaisen puutarha- ja maatilayrityksen analyysi. Tutkimustapaustilalla haastateltiin tilan emäntää, kolmea pitkäaikaista ja yhtä uutta vierastyöntekijää. Lisäksi järjestettiin työnantajan ja työntekijöiden ryhmähaastattelu (työpaja). Venäjänkielisten työntekijöiden kanssa keskusteltaessa käytettiin kielitaitoista tutkijaa. Haastattelujen teemoina olivat työntekijöiden perehdytyksen tarpeelliset asiakohdat. Haastatteluaineistoa käytettiin etnografisesti tilan toiminnan kuvaamiseen ja ryhmähaastattelusta tehtiin lisäksi diskurssianalyysi, jossa keskityttiin toimija-asemien rakentumiseen vuorovaikutuksessa (Harre \& Langenhove 1999; Niska \& Vesala 2011) Haastatteluaineistoa hyödynnettiin työnantajille lähetetyn kyselyn suunnittelussa. Kysely tehtiin Maaseudun Työnantajaliittoon kuuluville puutarha- ja maatilatyönantajille. Kyselystä tähän artikkeliin tehdyssä analyysissa kysymyksenä oli, käyttävätkö puutarha- ja maatilayrittäjät palkkatyövoimaa työnjohtotehtävissä, ja minkälaisena johtamiskeinona se tässä yhteydessä näyttäytyy?

Lomakkeessa käytetyssä työnjohtotehtäviä koskevassa mallissa oli 36-kohtainen lista perehdytyksessä esiintyvistä tehtävistä. Vastaajat arvioivat tehtäviä neliportaisella likert -asteikolla. Kyselyn analyysin avulla tarkasteltiin työnjohtotehtävien delegoinnin yleisyyttä, tärkeyttä ja vaativuutta verrattuna muihin työnjohtotehtäviin. Tämän jälkeen tutkittiin, voidaanko työnjohtotehtävien delegointia ennustaa joko maatilayritykseen liittyvillä piirteillä tai työnantajan sosio-demografisilla taustatekijöillä. Analyysia varten muodostettiin kysymyksistä viisi summamuuttujaa. 


\section{Tutkimustapauksen tarkastelu}

Tutkimustapauksena oleva yritys on Kaakkois-Suomessa toimiva marjatila. Tilan peltoala on laajentunut 10 vuodessa 15 hehtaarista 70 hehtaariin. Tilalla on vuosittain noin 100-150 kausityöntekijää. Yrittäjäpariskunnasta emäntä vastaa tilan työntekijöistä ja isäntä koneista. Työntekijöitä on peltotöissä, konetöissä (traktoriajo, tuotekuljetus ja varastointi), pakkauksessa, laaduntarkkailussa ja myynnissä (torimyynti). Noin viidesosa työntekijöistä on suomalaisia ja loput ulkomaalaisia. Tilalla on työntekijäyhteistyötä muiden yritysten kanssa mutta kausityöntekijöitä rekrytoidaan myös suoraan ulkomailta ja eniten Venäjältä. Emäntä on opetellut hoitamaan työluvat lähetystöjen kautta.

Tilan emäntä (E) kuvaili, miten työnjohtotehtäviä on tilalla delegoitu useille eri työntekijöille:

E: "tämä marjanpoiminta-aika niin sillon meillä on pellolla monta semmosta, jotka opastavat siihen poimintatyöhön oisko ollu seitsemän naista... ja sitten katsovat laatua että se on tuota ilman munta jaettu että en minä sitä itse pysty tekemään kaikkien kanssa. Ja sitten tietenkin tämä taloon tulo ... yritän tervehtiä aina, kun unudet ihmiset tulevat mutta sitten on "T", jonka harteilla on kyllä valtava homma siinä, kun hän ottaa heidät vastaan ja näyttää missä he astrvat, jakaa työasut... ja sitten hän on vaa'alla kirjoittamassa poimintatuloksia, että hänellä on kyllä valtava vastun siinä vaiheessa. Ja on meillä tietysti muitakin tämmösiä. "V:n" työtehtävät on nykyään kastelulaitehuollossa... hoitaa hyvin itsenäisesti sitä, poiminta-aikana autonkuljettajana, rakennustöissä ja metsätöissä, ja sitten kylmiössä on oma vastunhenkilö tämä " $J$ " ja siellä hänellä taas on muntama alainen ... sekä " $N$ " vielä peltopomona näyttää että tuolta ei ole poimittu (naurua)..."

Työnjohtamisessa on olennaista arvioida työntekijöiden valmiuksia ja ajattelua. Tämän merkitys korostuu erityisesti työnjohtotehtävien delegoinnissa. Seuraava sitaatti näyttää, miten tutkimustapaustilalla emäntä osaa arvioida työnjohtotehtävien delegointia ja eritellä sen merkitystä työntekijöiden välisten suhteiden kannalta:

E: "no tuota ite jäin miettimään että mulle tuli heti mieleen että sen takia on hyvä tutustua näihin tai_tuntea kuka tekee mitäkin ja myös siksikin kun on nostettu näihin pomohommiin niin tämmönen uusi tulokas voi arvella että miten tuokin voi olla jo tommosissa pomotöissä... aina kun heitä nostetaan pomohommiin niin he ovat todella ansioituneita, ovat olleet hyviä työntekijöitä monta vuotta... ja jos on oikeat pomot valittu niin tuota sittenhän siihen tulee semmonen sitoutuminen niillä työntekijöillä että täällä on mahdollista päästä sitten muihinkin tehtäviin."

Tilalla on parikymmentä pitkäaikaista työntekijää, joista useille on delegoitu työnjohtotehtäviä. Yksilöhaastatteluissa mukana olleet pitkäaikaiset työntekijät vakuuttivat olevansa hyvin tyytyväisiä, vaikka toisaalta kuvasivat työn rankaksi ja myös epämieluisia työtehtäviä sisältäväksi. He sanoivat että heitä arvostetaan, kohdellaan hyvin, heille annetaan vastuuta ja he saavat hyvän korvauksen työstä. Yrittäjät näyttävät siis onnistuneen heidän palkitsemisessaan ja sitouttamisessaan.

Ryhmähaastattelussa oli mukana tutkimustapaustilan emäntä, kaksi pitkäaikaista työntekijää (mies "V", nainen "I") ja kolme tutkijaa. Viisituntisessa työpajassa työntekijöiden perehdyttämiseen liittyvät työnjohtoteemat toimivat keskustelun virikkeinä. Tutkijat esittelivät teemat ja keskustelua ylläpitävät lisäkysymykset antaen tilaa emännän ja työntekijöiden puheenvuoroille. Emännän puheenvuorot olivat vallitsevia. Muutamia kertoja työntekijät ottivat puheenvuoron oma-aloitteisesti ja lisäksi haastattelussa käytiin usein vuoropuhelua työntekijöiden ja emännän kesken.

Haastattelunauhoituksen diskurssianalyysissa kiinnitettiin huomiota emännän ja työntekijöiden väliseen yhteistoiminnallisuuteen keskustelussa ja siihen, minkälaiseksi työntekijöiden toimija-asema rakentui yhtäältä näiden omassa ja toisaalta emännän puheessa. Emäntä kiitteli työntekijöiden vastuunkantamista ja käsitteli kommenttipyynnöissään heitä ulkomaalaisten kausityöntekijöiden kulttuuritaustan ja ajattelutapojen asiantuntijoina. Työntekijät tarttuivat innolla näihin pyyntöihin ja esimerkiksi erittelivät sen tärkeyttä, että eri taustoista olevia tutustutetaan toisiinsa ja että kaikkia kohdellaan samanarvoisesti. Työntekijät osallistuivat aktiivisesti kausityöntekijöiden rekrytointia ja motivointia koskevaan pohdintaan. He arvioivat näiden taitoja ja valmiuksia, asenteita ja käytöstapoja, rakentaen itselleen työntekijöiden "psykologiaa" hallitsevan ja nimenomaan työnjohtamisen näkökulmasta asioita katsovan toimijan asemaa. Esimerkiksi emännän todettua työnseurannan välttämättömäksi taimien istutuksessa jatkoi toinen työntekijöistä: "pitää olla joku syy tehdä asiat hyvin että siksi on minusta oikein että kontrolloidaan." 
Haastattelussa mukana olleet työntekijät asettuivat puheessaan työnjohtoa edustavan toimijan asemaan; he siis osaavat näin toimia ja näkevät tämän odotuksen mukaiseksi. Emäntä taas tahollaan osasi kannustaa ja antaa heille tilaa tähän, säilyttäen silti ongelmitta oman asemansa näiden johtajana. Hän esimerkiksi kutsui työntekijät pohtimaan rekrytoitavien kausityöntekijöiden sopivaa lukumäärää:
E: $\quad$ "mie oikeestaan voisin kysyä että onko parempi että meillä on vähän liikaa väkeä vai pikkusen niinku puntetta väestä?"
I: "jos on liian paljon työntekijöitä, työpäivät jäävät lyhyeksi, ihmiset eivät tiedä mitä tehdä ja palkat ovat pienemmät, jos taas vähän työntekijöitä päivät ovat pitkiä... niin väsyy"
V: "riippuı ihmisestä..."
E: $\quad$ "jos on niukkuntta ihmisistä ja me joudutaan tekemään vaikka neljä viikkoa, ettei ole yhtään vapaapäivää niin kyllä sillon huomaa että kaikki on ihan ärtyneitä ja on pakko ottaa vapaapäivä vaikka tuotanto kärsisi..."
$\mathrm{V}: \quad$ "jos on oikein paljon ihmisiä, niin siitäkin seuraa huonoa, ensinnäkin on paljon ongelmia sen
kanssa että kaikki saisivat työtä ja työprosessien järjestäminen on myös vaikeaa."
I: "ennen oli vähemmän ihmisiä tilalla oli 20-30 ihmistä olimme pellolla aamusta iltaan ja halusimme tehdä töitä nyt on paljon ihmisiä jotka eivät halua tehdä töitä, jos on hyviä työntekijöitä riittää vähempikin huonoja tarvitsee enemmän."
$\mathrm{V}: \quad$ "jos on paljon ensimmäisen vuoden työntekijöitä heistä on vaikea sanoa ${ }_{2}$ kolmannen vuoden työntekijällä on jo paljon kokemusta työstä ja he voivat tehdä enemmän siksi ensimmäisen vuoden työntekijöillä on raskaampaa ja vasta toisena tai kolmantena vuonna alkaa kerätä hyvin ... (naurua) ensimmäinen vuosi on todella raskas ja ihmiset keräävät huonosti työhalu voi parantua ajan mittaan"

Tutkimustapaus osoittaa, että työnjohtotehtävien delegointi tiloilla on mahdollista. Tapaustilaa voidaan myös tulkita hyvänä esimerkkinä työnjohtotehtävien delegoinnin toteutuksesta henkilömäärältään suurella puutarhatilalla, ja sen vaatimista työnjohdollisista taidoista. Kyselytutkimuksessa tutkimme asian yleisyyttä ja sen koettua tärkeyttä laajemmin työnantajien keskuudessa.

\section{Kyselytulokset}

Kyselyanalyysissa tilat jaettiin tuotantosuunnan mukaan puutarha- ja muihin tiloihin. Tilan koko määritettiin vuonna 2010 tilalla työskennelleen ulkopuolisen työvoiman lukumäärän perusteella. Työantajan sosio-demografisista ominaisuuksista huomioitiin taustamuuttujina sukupuoli ja ikä. Taustamuuttujien tunnusluvut ja niiden väliset korrelaatiot esitellään taulukossa 1. Aineisto rajattiin tiloihin, joilla oli enemmän kuin yksi perheen ulkopuolinen työntekijä.

Työnjohtokysymyksistä koottiin viisi summamuuttujaa: 1) työsopimukset ja vakuntukset (palkanmaksuasioiden hoitaminen, työntekijän vakuutusten hoitaminen ja työsopimuksen laatiminen), 2) sosiaalinen infrastruktunuri (asuin- tai sosiaalitilojen järjestäminen, virkistystoiminnan järjestäminen työntekijöille, työterveyshuollon järjestäminen ja lähipalvelujen esittely), 3) työturvallisuııs (työntekijän työturvallisuuden seuranta ja työturvallisuusriskien tunnistaminen ja hallinta), 4) työn laadın hallinta (työn laadun valvonta ja työn tuloksellisuuden seuranta) sekä 5) Ihmissuhteet ja vuorovaikutus (vuorovaikutteinen viestintä työntekijöiden kanssa, hyvästä työilmapiiristä huolehtiminen, ristiriitojen kohtaaminen ja käsittely työntekijän kanssa, työntekijöiden välisten ristiriitojen käsittely, työntekijän motivointi ja työntekijän henkisen hyvinvoinnin tunnistaminen). Summamuuttujat tehtiin toimenpiteiden käytölle, tärkeydelle ja vaativuudelle.

Työnjohtamistoimenpiteiden käyttöä koskevaan kysymykseen vastasi yhteensä 87 työnantajaa. Näistä vastaajista vain 51 prosenttia vastasi delegoivansa työnjohtotehtäviä. Vastaavasti 61 prosenttia kaikista vastaajista $(\mathrm{N}=131)$ vastasi käyttävänsä työntekijöitä toisten työntekijöiden opastuksessa vähintään melko usein. Toisaalta varsinaisia palkattuja esimiehiä oli vain 21 prosentilla kyselyyn vastanneista tiloista $(\mathrm{N}=143)$. Verrattaessa muihin työnjohdollisiin toimenpiteisiin työnjohtotehtävien delegointi työntekijöille oli vähiten käytetty ( $0=$ ei käytössä, $1=$ käytössä, $N=84)$ : 
Vastaajista $(\mathrm{N}=124) 58$ prosenttia piti työnjohtotehtävien delegointia joko "tärkeänä" tai "erittäin tärkeänä". Kysyttäessä työntekijöiden käyttämisestä toisten työntekijöiden opastuksessa oli vastaava osuus 63 prosenttia. Työnjohtotehtävien delegointia joko tärkeänä tai erittäin tärkeänä pitäneitä oli siis enemmän kuin delegointia itse harjoittavia. Tämä seikka näkyi myös katsottaessa työntekijöiden käyttöä toisten työntekijöiden opastuksessa. Vaikka suurin osa vastaajista arvotti työnjohtotehtävien delegoinnin tärkeäksi, niin he arvottivat keskimäärin vielä tärkeämmiksi muut johtamistoimen tehtävät ( $1=$ ei tärkeä, $4=$ erittäin tärkeä, $\mathrm{N}=123$ ):

1. jösopimukset ja vakiuutukset $(k a=3,6, k h=0,6, a=0,76)$, 2. työn laadunhallinta $(k a=3,6, k h=0,5, a=0,67), 3$.

gö̈tumallisuns $(k a=3,5, k h=0,5, a=0,76), 4$. ihmissuhteet ja vuorovaikutus $(k a=3,4, k h=0,5,0=0,85,5$, sosiaalinen

infíastukumui $(k a=2,7, k h=0,7, a=0,66), 6$. työmjohtotehtävien delegointi toöntekijöille $(k a=2,7, k h=1,0)$.

Tarkasteltaessa työnjohtotoimenpiteiden vaativuutta rajauduttiin vastaajiin, jotka arvottivat työnjohtotehtävien delegoinnin vähintään kohtalaisen tärkeäksi. Näistä vastaajista $(\mathrm{N}=95) 77$ prosenttia katsoi työnjohtotehtävien delegoinnin joko "melko" tai "erittäin vaativaksi", ja vastaavasti ainoastaan 23 prosenttia "ei yhtään" tai vain "vähän vaativaksi". Kysyttäessä työntekijöiden käytöstä toisten työntekijöiden opastuksessa, vastaajista $(\mathrm{N}=110)$ peräti 73 prosenttia katsoi toimenpiteen "helpoksi" tai "melko helpoksi". Siten työntekijöiden käyttö toisten työntekijöiden opastuksessa nähtiin keskimäärin helpompana kuin muu työnjohtotehtävien jakaminen. Vaativimmiksi työnjohtotoimenpiteiksi arvioitiin ihmissuhteiden ja laadun hallinta, työnjohtotehtävien delegointi ja työturvallisuus. Sopimusteknisten ja infrastruktuurin hallintatehtävät olivat helpompia ( 1 =ei yhtään vaativaa, $4=$ =rittäin vaativaa, $\mathrm{N}=87$ ):

1 ihmissuhteet ja vuorovaikutus $(k a=3,1, k h=0,6, a=0,82)$, 2. työn laadun hallinta $(k a=3,0, k h=0,7, a=0,75), 3$. työnjohtotehtävien delegointi työntekijöille $(k a=3,0, k h=0,8)$, 4. työturvallisuus $(k a=2,9, k h=0,8, a=0,87), 5$. työsopimukset ja vakuutukset $(k a=2,2, k h=0,8, a=0,86)$, 6. sosiaalinen infrastuktuari $(k a=2,2, k h=0,6, a=0,66)$.

Tilan luonnetta kuvaavista taustamuuttujista työnjohtotehtävien delegointi korreloi erityisesti kausittaisen työvoiman määrään (Taulukko 1). Siinä missä 51 prosenttia kaikista vastaajista ilmoitti harjoittavansa työnjohtotehtävien delegointia, vähintään viiden kausityöntekijän tiloista $(\mathrm{N}=22)$ työnjohtotehtäviä delegoivien osuus oli 68 prosenttia ja vähintään kymmenen kausityöntekijän tiloista $(\mathrm{N}=12)$ jo 92 prosenttia. Sosio-demografisista taustatekijöistä delegointia ennakoivat työnantajavastaajan naissukupuoli ja nuori ikä.

Arviot delegoinnin tärkeydestä korreloivat positiivisesti sekä tilan kausittaisen että ulkomaalaistaustaisen työvoiman määrään (taulukko 1). Osittaiskorrelaatioiden perusteella ensisijainen ennustava tekijä oli kuitenkin kausityövoima; ulkomaalaistaustaisen työvoiman määrä ennusti delegoinnin tärkeyttä lähinnä siksi, että tämä työvoima oli tyypillisesti myös kausittaista (kun tilan kausittaisen työvoiman määrä vakioitiin, ei ulkomaalaistaustaisen työvoiman määrällä ollut ennustavaa vaikutusta).Sosio-demografiset taustatekijät eivät merkitsevästi ennustaneet tärkeysarvioita, joskin naistyönantajat arvottivat työnjohtotehtävien delegoinnin jossain määrin tärkeämmäksi kuin miestyönantajat (taulukko 1).

Työnjohtotehtävien delegoinnin koettua vaativuutta eivät ennustaneet merkitsevästi tilaa tai työnantajaa kuvaavat taustatekijät. Sen sijaan delegoinnin vaativuus korreloi positiivisesti sekä sen harjoittamiseen että arvioihin sen tärkeydestä. Usein vastaajat katsoivat delegoinnin vaikeaksi silloin, kun itse sitä harjoittivat ja pitivät tärkeänä. Myös tärkeyden ja harjoittamisen välillä oli positiivinen yhteys. (Taulukko 1.)

Toinen tarkastelemamme delegointitapa, työntekijän käyttö toisten työntekijöiden opastuksessa, riippui edellä mainituista taustatekijöistä pääosin samansuuntaisesti kuin ensin käsitelty delegointitapa, joskaan työantajan nuori ikä ei ennustanut tätä delegointitapaa. Tätä delegointitapaa käyttivät keskimäärin useammin puutarhatilojen työnantajat. Tämän delegointitavan yleisyys ja tärkeys eivät riippuneet yhtä voimakkaasti kausittaisen työvoiman määrästä, mutta vastaavasti voimakkaammin puutarhaviljelystä tuotantosuuntana. Arviot delegointitavan tärkeydestä korreloivat positiivisesti delegointitavan yleisyyteen ja vastaavasti delegointitavan vaikeana pitäminen vähensi todennäköisyyttä delegoida. Lisäksi havaittiin, että delegointia tärkeänä tai erittäin tärkeänä pitäneet, mutta silti korkeintaan harvoin harjoittaneet työnantajat pitivät delegointia vaikeampana kuin muut vastaajat $(\mathrm{t}(119)=3,89, \mathrm{p}<0,001)$. 
Taulukko 1. Taustamuuttujien tunnusluvut sekä korrelaatiot työnjohtotehtävien delegoinnin käyttöön, tärkeyteen ja vaikeuteen.

\begin{tabular}{|c|c|c|c|c|c|c|c|c|c|c|c|c|}
\hline & $\mathrm{Ka}(\mathrm{kh})$ & 1. & 2. & 3. & 4. & 5. & 6. & 7. & 8. & 9. & 10. & 11. \\
\hline $\begin{array}{l}\text { 1. Tuotantosuunta } \\
\text { (puutarhaviljely) }\end{array}$ & $\begin{array}{l}0,5(0,5) \\
\mathrm{N}=143\end{array}$ & - & & & & & & & & & & \\
\hline 2. Pysyvān tyōvoiman māảrã & $\begin{array}{l}3,0(7,9) \\
\mathrm{N}=143\end{array}$ & $\begin{array}{l}0,15 \\
\mathrm{~N}=143\end{array}$ & - & & & & & & & & & \\
\hline $\begin{array}{l}\text { 3. Kausittaisen tyôvoiman } \\
\text { māârā }\end{array}$ & $\begin{array}{l}6,0(16,6) \\
\mathrm{N}=143\end{array}$ & $\begin{array}{l}0,27 * * \\
\mathrm{~N}=143\end{array}$ & $\begin{array}{l}-0,12 \\
\mathrm{~N}=143\end{array}$ & - & & & & & & & & \\
\hline $\begin{array}{l}\text { 4. Ulkomaalaistaustaisen } \\
\text { tyôvoiman māārā }\end{array}$ & $\begin{array}{l}4,5(17,4) \\
\mathrm{N}=143\end{array}$ & $\begin{array}{l}0,22 * * \\
\mathrm{~N}=143\end{array}$ & $\begin{array}{l}0,02 \\
\mathrm{~N}=143\end{array}$ & $\begin{array}{l}0,84^{* *} \\
\mathrm{~N}=143\end{array}$ & - & & & & & & & \\
\hline $\begin{array}{l}\text { 5. Tyônantajavastaajan } \\
\text { sukupuoli (mies) }\end{array}$ & $\begin{array}{l}0,7(0,5) \\
\mathrm{N}=140\end{array}$ & $\begin{array}{l}0,04 \\
\mathrm{~N}=140\end{array}$ & $\begin{array}{l}0,07 \\
\mathrm{~N}=140\end{array}$ & $\begin{array}{l}-0,08 \\
\mathrm{~N}=140\end{array}$ & $\begin{array}{l}-0,06 \\
N=140\end{array}$ & - & & & & & & \\
\hline 6. Tyōnantajavastaajan ikā & $\begin{array}{l}49,6(9,5) \\
\mathrm{N}=142\end{array}$ & $\begin{array}{l}0,03 \\
\mathrm{~N}=142\end{array}$ & $\begin{array}{l}0,08 \\
N=142\end{array}$ & $\begin{array}{l}-0,07 \\
N=142\end{array}$ & $\begin{array}{l}-0,03 \\
\mathrm{~N}=142\end{array}$ & $\begin{array}{l}0,15 \\
N=139\end{array}$ & - & & & & & \\
\hline $\begin{array}{l}\text { 7. Tyōnjohtotehtãvien } \\
\text { delegointi (kãyttô) }\end{array}$ & - & $\begin{array}{l}0,13 \\
N=87\end{array}$ & $\begin{array}{l}0,09 \\
N=87\end{array}$ & $\begin{array}{l}0,25^{*} \\
\mathrm{~N}=87\end{array}$ & $\begin{array}{l}0,19 \\
N=87\end{array}$ & $\begin{array}{l}0,30^{* *} \\
\mathrm{~N}=85\end{array}$ & $\begin{array}{l}-0,23 * * \\
\mathrm{~N}=87\end{array}$ & - & & & & \\
\hline $\begin{array}{l}\text { 8. Tyōntekijān kãyttāminen } \\
\text { toisten op astuksessa (yl eisyys) }\end{array}$ & - & $\begin{array}{l}0,30^{* *} \\
\mathrm{~N}=131\end{array}$ & $\begin{array}{l}0,15 \\
\mathrm{~N}=131\end{array}$ & $\begin{array}{l}0,15 \\
N=131\end{array}$ & $\begin{array}{l}0,13 \\
\mathrm{~N}=131\end{array}$ & $\begin{array}{l}-0,18^{*} \\
N=129\end{array}$ & $\begin{array}{l}0,09 \\
N=130\end{array}$ & $\begin{array}{l}0,41^{* *} \\
\mathrm{~N}=85\end{array}$ & - & & & \\
\hline $\begin{array}{l}\text { 9. Tyōnjohtotehtāvien } \\
\text { delegointi (târkeys) }\end{array}$ & - & $\begin{array}{l}0,16 \\
N=124\end{array}$ & $\begin{array}{l}0,01 \\
\mathrm{~N}=124\end{array}$ & $\begin{array}{l}0,27^{* *} \\
\mathrm{~N}=124\end{array}$ & $\begin{array}{l}0,23^{*} \\
\mathrm{~N}=124\end{array}$ & $\begin{array}{l}-0,12 \\
\mathrm{~N}=121\end{array}$ & $\begin{array}{l}-0,02 \\
\mathrm{~N}=123\end{array}$ & $\begin{array}{l}0,49 * * \\
\mathrm{~N}=74\end{array}$ & $\begin{array}{l}0,40^{* *} \\
\mathrm{~N}=117\end{array}$ & - & & \\
\hline $\begin{array}{l}\text { 10. Tyōntekijān kāyttāminen } \\
\text { toisten opastuksessa (tärkeys) }\end{array}$ & - & $\begin{array}{l}0,26^{* *} \\
\mathrm{~N}=124\end{array}$ & $\begin{array}{l}0,14 \\
N=124\end{array}$ & $\begin{array}{l}0,21^{*} \\
\mathrm{~N}=124\end{array}$ & $\begin{array}{l}0,17 \\
\mathrm{~N}=124\end{array}$ & $\begin{array}{l}-0,09 \\
N=122\end{array}$ & $\begin{array}{l}0,00 \\
N=124\end{array}$ & $\begin{array}{l}0,38^{* *} \\
\mathrm{~N}=84\end{array}$ & $\begin{array}{l}0,71 * * \\
\mathrm{~N}=124\end{array}$ & $\begin{array}{l}0,44^{* *} \\
N=110\end{array}$ & - & \\
\hline $\begin{array}{l}\text { 11. Tyônjohtotehtāvien } \\
\text { delegointi (vaikeus) }\end{array}$ & - & $\begin{array}{l}0,02 \\
N=95\end{array}$ & $\begin{array}{l}-0,04 \\
\mathrm{~N}=95\end{array}$ & $\begin{array}{l}0,12 \\
N=95\end{array}$ & $\begin{array}{l}0,09 \\
\mathrm{~N}=95\end{array}$ & $\begin{array}{l}-0,04 \\
N=92\end{array}$ & $\begin{array}{l}-0,02 \\
\mathrm{~N}=95 \\
\end{array}$ & $\begin{array}{l}0,19 \\
N=63\end{array}$ & $\begin{array}{l}0,02 \\
\mathrm{~N}=91\end{array}$ & $\begin{array}{l}0,14 \\
N=95\end{array}$ & $\begin{array}{l}0,22^{*} \\
\mathrm{~N}=89\end{array}$ & . \\
\hline $\begin{array}{l}\text { 12. Tyōntekijān kãyttāminen } \\
\text { toisten opastuksessa (vaikeus) }\end{array}$ & - & $\begin{array}{l}-0,24^{*} \\
\mathrm{~N}=110\end{array}$ & $\begin{array}{l}0,06 \\
N=110\end{array}$ & $\begin{array}{l}-0,14 \\
N=110\end{array}$ & $\begin{array}{l}-0,13 \\
N=110\end{array}$ & $\begin{array}{l}0,06 \\
N=108\end{array}$ & $\begin{array}{l}0,15 \\
N=110\end{array}$ & $\begin{array}{l}-0,02 \\
\mathrm{~N}=73\end{array}$ & $\begin{array}{l}-0,37 * * \\
\mathrm{~N}=110\end{array}$ & $\begin{array}{l}-0,08 \\
\mathrm{~N}=96\end{array}$ & $\begin{array}{l}-0,12 \\
\mathrm{~N}=110\end{array}$ & $\begin{array}{l}0,13 \\
N=79\end{array}$ \\
\hline
\end{tabular}

*) $p<0,05 ; * \eta p<0,01$.

Huom. Tuotantosuunta (puutarhaviljely=1, muu=0); pysycön, kausittaisen ja ulkomaalaisen työroiman määrā vuonna 2010; työnantajavastaajan sukupuoli (mies=1, nainen=0)

${ }^{1}$ Toimenpidettā văhintāōn kohtalaisen târkeänā pitäneet vastaajat.

\section{Johtopäätökset}

Runsas työvoiman käyttö asettaa johtamishaasteita yrittäjille. Kaikkea työnjohtoon liittyvää ei ehdi tehdä itse. Työnjohtotehtävien delegointi työntekijöille auttaa yrittäjän omassa ajanhallinnassa. Samalla se mahdollistaa lisääntyvää työvoiman käyttöä ja yritystoiminnan laajentamista. Tutkimustapauksena ollut tila oli kasvanut voimakkaasti ja kausityöntekijöiden vuosittainen määrä oli jo toista sataa. Useanlaisia työnjohtotehtäviä oli delegoitu pitkäaikaisille työntekijöille. Järjestelyä oli kehitetty pitkäjänteisesti ja määrätietoisesti. Tutkimustapauksen analyysi toi esiin työnjohtotehtävien delegoimisen onnistuneeseen toteuttamiseen liittyviä organisointi- ja vuorovaikutuskäytänteitä ja niissä tarvittavia taitoja.

Kyselyaineiston mukaan työnjohtotehtävien delegointi työntekijöille on hyvin yleistä vähintään kymmenen kausityöntekijän tiloilla. Tätä vähemmän ulkopuolista kausityövoimaa käyttävistä tiloista vain noin puolet ilmoittaa käyttävänsä sitä. Käyttöä ennustavia tekijöitä olivat myös työnantajavastaajan naissukupuoli ja nuori ikä sekä puutarhaviljely tuotantosuuntana Työnjohtotehtävien delegointia työntekijöille pidettiin yleisesti ottaen tärkeänä ja vaativana työnjohtotoimenpiteenä. Työnjohtotehtävien delegoinnin arvioitu tärkeys lisääntyi, kun tiloilla oli ulkomaalaista kausityövoimaa, joskin työvoiman kausiluontoisuus oli tässä sen ulkomaalaisuutta merkityksellisempää.

Työnjohtotehtävien delegointi on siis yleisintä suurilla tiloilla ja näillä tiloilla se myös koetaan tärkeäksi. Toisaalta delegointia harjoittavat yrittäjät näkevät sen vaativana menettelynä. Tutkimustapauksen valossa nämä tulokset ovat ymmärrettäviä, sillä työnjohtotehtävien delegointi näyttää sekä mahdollistavan työvoiman käytön laajentamista että edellyttävän asianmukaisia, organisointiin ja vuorovaikutukseen liittyviä työnjohdollisia taitoja. Näitä taitoja ilmentävien hyvien käytänteiden välittyminen ja taitojen kehittämistä tukevan tutkimuksen, koulutuksen ja neuvonnan tarjonta selvästikin palvelisi suurten työvoimamäärien puutarha- ja maatilayrityksiä. Tilojen laajentamiseen vievän rakennekehityksen ja siihen liittyvien johtamishaasteiden kannalta voidaan ajatella, että työnjohtotehtävien delegointi työntekijöille olisi erityisen huomionarvoinen seikka pienemmillä, työvoimamääräänsä mahdollisesti kasvattavilla tai sitä aikovilla tiloilla, joilla delegoinnin käyttäminen ei ole niin yleistä kuin isoimmilla tiloilla eivätkä sen edellyttämät taidot ja käytänteet näin ollen vielä ole ehtineet kehittyä. Tätä tulisi tutkia lisää. Jos tiloilla mahdollisesti ei nähdä tiettyjen johtamistehtävien tärkeyttä, tehtävien ennakoitu vaativuus voi estää hyödyllisten johtamiskeinojen kuten delegoinnin käyttöönottoa, mikä voi hillitä työvoiman käyttöä ja tilan kasvua. 


\section{Kirjallisuus}

Aaltonen, R. ja Heikkilä, H. (eds). 2011. Tuota ja hanki urakointipalveluja. Tieto tuottamaan 135. ProAgria keskusten liitto. Otava. Keuruu.

Harre, R. ja van Langenhove, L. (eds.). 1999. Positioning Theory. Oxford U.K: Blackwell.

Karttunen, J., Tuure, V-M., Kaila, E. 2008. Maatilan töiden organisointi. Julkaisussa: Pasi Rikkonen, Taina Harmoinen, Hanne Teräväinen (toim.). Maatilayrityksen menestystekijät. Maaseutukeskusten Liiton julkaisuja 1056: Tieto tuottamaan 123: p. 33-41.

Kinnunen, B., Kivinen, T., Leppälä, J., Lätti, M., Mattila, T., Partanen, U., Raussi, S., Rautiainen, R., Sinisalo, A., Suutarinen, J., Taattola, K., Tuure, V-M. 2010. Työntekijöiden perehdyttäminen ja työnopastus puutarha- ja maataloustuotannossa. TTS tutkimuksen raportteja ja oppaita 43. Nurmijärvi 2010.

Leppälä, J., Tuure, V-M., Sinisalo, A., Kaila, E., Suutarinen, J., Rikkonen, P., Rantamäki-Lahtinen, L. 2008. Maatilan johtaminen. Julkaisussa: Pasi Rikkonen, Taina Harmoinen, Hanne Teräväinen (eds.). Maatilayrityksen menestystekijät. Maaseutukeskusten Liiton julkaisuja 1056:Tieto tuottamaan 123: p. 33-41.

Niska, M. ja Vesala, K.M. 2011. Moninaistuva politiikka, moninaistuva yrittäjyys? Toimijapositioiden rakentuminen yrittäjyyden edistämisdiskursseissa Teoksessa Vesala, K.M. \& Vihinen, H. (toim.) Yritysten menestystarinat ja yrittäjyyden edistäminen. Tapaustutkimus yrittäjistä, kehittäjistä ja politiikkadiskursseista Sunpohjan seutukunnassa. MTT Raportti 16. Jokioinen.p. 94-128.

Ovaska, U., Leppälä, J., Mattila, T. ja Sinisalo, A. 2011. Ulkomainen kausityövoima maatiloilla. Maaseudun uusi aika 2/2011.

Rekola, V-M. 2003. Työnantajana toimiminen. Julkaisussa: Enroth, A., Österman, P. \& Teräväinen, H. (eds.). Laajentavien tilojen haasteet. ProAgria Maaseutukeskusten Liitto. Tieto tuottamaan 104: 86-96.

Vartiainen, M. Teikari, V. ja Pulkkis, A. 1989. Psykologinen tyo $\square$ nopetus. Espoo: Otakustannus.

Vesala, K. ja Pyysiäinen, J. 2008. Understanding Entrepreneurial Skills in the Farm Context. Hankeraportti. Research Institute of Organic Agriculture (FiBL). $485 \mathrm{~s}$. 